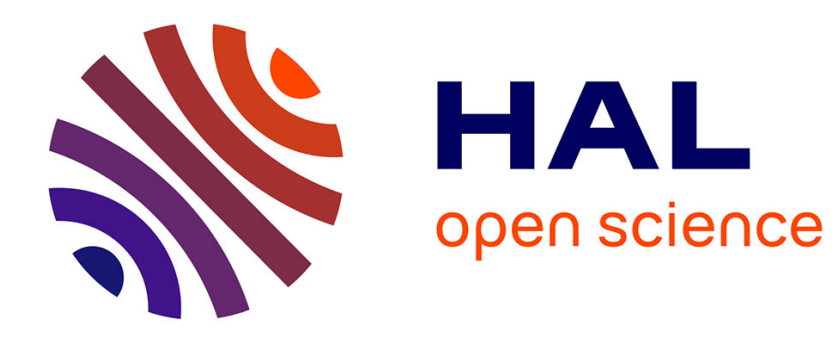

\title{
Natesto®. What Else? New Trends in Drug Naming Pascaline Faure
}

\section{To cite this version:}

Pascaline Faure. Natesto®. What Else? New Trends in Drug Naming. Names: A Journal of Onomastics, 2018, 66 (2), pp.65-74. 10.1080/00277738.2017.1415532 . hal-03510320

\section{HAL Id: hal-03510320 https://hal.science/hal-03510320}

Submitted on 4 Jan 2022

HAL is a multi-disciplinary open access archive for the deposit and dissemination of scientific research documents, whether they are published or not. The documents may come from teaching and research institutions in France or abroad, or from public or private research centers.
L'archive ouverte pluridisciplinaire HAL, est destinée au dépôt et à la diffusion de documents scientifiques de niveau recherche, publiés ou non, émanant des établissements d'enseignement et de recherche français ou étrangers, des laboratoires publics ou privés. 


\section{Names}

A Journal of Onomastics

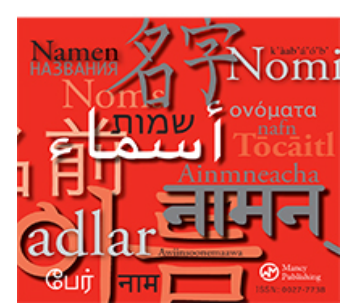

ISSN: 0027-7738 (Print) 1756-2279 (Online) Journal homepage: http://www.tandfonline.com/loi/ynam20

\section{Natesto ${ }^{\circledR}$. What Else? New Trends in Drug Naming}

\section{Pascaline Faure}

To cite this article: Pascaline Faure (2018): Natesto ${ }^{\circledR}$. What Else? New Trends in Drug Naming, Names, DOI: 10.1080/00277738.2017.1415532

To link to this article: https://doi.org/10.1080/00277738.2017.1415532

Published online: 03 Jan 2018.

Submit your article to this journal $₫$

Q View related articles $₫$

View Crossmark data \lceil 


\title{
Natesto ${ }^{\circledR}$. What Else? New Trends in Drug Naming
}

\author{
PASCALINE FAure
}

Pierre and Marie Curie School of Medicine, Sorbonne University, Paris, France

This paper is a lexicological study of the brand names of newly FDA (Food and Drug Administration) approved drugs which aims at highlighting the new trends observed in drug naming. For our corpus, we used a listing of 320 drugs approved by the FDA for sale in the United States for the years 2012 to 2017. In our study, we showed that the commonly used letters $X$ and $Z$ were giving way to $A$ and $O$ endings so as to attract Romance languages speaking clients. We demonstrated that this trend matched a less recent ploy in food and automotive marketing. We focused on the "Vowel/Consonant+lexeme" matrix that is found almost exclusively in the drug industry because it permits to create a name shorter in writing - an advantage for prescribers. Although the FDA recommended that "unsubstantial beneficial" connotations be banned, we uncovered the presence of promotional affixes as well as hidden emotional contents that are meant to be persuasive.

KEYWORDS Onomastics, pharmaceutical drug, brand name, phonosemantics, marketing.

\section{Introduction - From the molecule to the brand}

In the pharmaceutical industry, a brand (proprietary) name is created by the company that patents the drug and will be used during all the years of protection (up to 20 years for a patent and between I9o days and seven years for exclusivity protection ${ }^{\mathrm{I}}$ ). The Center for Drug Evaluation and Research (CDER) within the Food and Drug Administration (FDA) reviews proposed drug names prior to the marketing of a drug to minimize user errors attributed to confusing nomenclature (mostly product names that look or soundalike or those overly fanciful or promising ${ }^{2}$ ). For instance, for the quit-smoking drug that contained varenicline, unlike the European Medical Agency (EMA), the FDA denied Pfizer the right to call it Champix ${ }^{\circledR}$ on the grounds that it was misleading by making misrepresentations with respect to efficacy (indeed, the name was judged too close to 
the notion of "championship"). Therefore, Pfizer had to change it into Chantix ${ }^{\circledR}$ for the US market.

A company can give a patented drug different brand names depending on whether the version of the drug is the one that is reimbursed by health insurance companies (e.g. Revatio $^{\circledR}$ ) or not (e.g. Viagra $\left.{ }^{\circledR}\right)$.

Drug companies can spend as much as $2,500,000$ dollars just to come up with a medicine's name. Beyond the cost, the stakes are all the higher as the FDA rejects about four out of ro proposed brand names for new drugs. Therefore, pharmaceutical companies usually address global branding firms.

We propose to review the latest trends in drug naming based on the hypothesis that they are part of a much larger global branding strategy that encompasses other industries such as that of automotive and food. Our corpus is made of 320 drugs that were approved by the FDA between 2012 and 2017 . In the first part, we review the FDA's set of recommendations in developing proprietary names for the pharmaceutical industry, which was released in May 20I4. The second part will be devoted to the prevalence of some letters. In the third part, we will focus on a popular matrix "a consonant/vowel+a (meaningful or meaningless) lexeme". In the fourth part, we will concentrate on culture-related sound symbolism and more precisely on what we name "Italianization". The fifth part will deal with word-conveyed connotation.

Drug companies are extremely reluctant to avow the reasons that prompted their choice of a given name. We faced the same code of silence from branding institutes. Some brand names were obvious but the thinking that lay behind others was difficult to comprehend. Therefore, many analyses are our own as a linguist with medical background. They are based on our knowledge of Germanic and Romance languages and of Greek and Latin roots. Our corpus was analyzed manually.

\section{FDA's guidance}

In May 20I4, the FDA issued a set of recommendations in developing proprietary names for the pharmaceutical industry ${ }^{3}$. Henceforth, the pharmaceutical industry and its drug sponsors should eliminate names with obvious similarities to the names of existing products (e.g. Mirapex ${ }^{\circledR}$, an antiparkinsonian, and Miralax ${ }^{\circledR}$, a laxative), and medical abbreviations, symbols, and dose designations (e.g. IU "International Unit" and IV "Intra-venous"). Their reason is that patients might not understand or might be confused with the abbreviations that are commonly used such as SR (Sustained Release) and XL (Extended Release): Wellbutrin $\mathrm{SR}^{\circledR}$ is taken twice a day while Wellbutrin $\mathrm{XL}^{\circledR}$ is taken once a day. Another example is Addyi ${ }^{\circledR}$, a non-hormonal prescription pill used to treat hypoactive sexual desire disorder (HSDD) in women, whereas the abbreviation ADD means attention deficit disorder as in Adderall ${ }^{\circledR}$.

Sponsors should avoid any reference to an inert or inactive ingredient (e.g. aspartame or magnesium stearate), and the name of one or more, but not all, of its active ingredients (e.g. a drug that contains ibuprofen and pseudoephedrine and whose name would only be known to contain ibuprofen). For example, Advil ${ }^{\circledR}$ is known to contain ibuprofen but Rhinadvil ${ }^{\circledR}$ also contains pseudoephedrine. 
Sponsors should not use United States Adopted Name (USAN) stems ${ }^{4}$ (e.g. using -ast that designates antiasthmatics in a drug that is an anti-ulcer proton-pump inhibitor such as $\left.\operatorname{Ogast}^{\mathbb{B}}\right)$, as these roots are used exclusively for making generic drug names.

The same proprietary name or the same root proprietary name for products that do not contain at least one common active ingredient contained in the original should be avoided. For instance, Rhinathiol Syrup ${ }^{\circledR}$ contains carbocysteine, a mucolytic, but has two other versions: one for dry cough that does not contain carbocysteine but pholcodine, a cough suppressant, and one that associates promethazine to carbocysteine, called Rhinathiol Promethazine ${ }^{\circledR}$.

Sponsors are also recommended to avoid incorporating product-specific attributes as part of the proposed proprietary name (e.g. Prevacid Solutab ${ }^{\circledR}$ ), and names that are constructed of a root proprietary name accompanied by potentially confusing modifiers. In 20I6, the company that manufactures Nurofen $\left(\right.$ Nurofen $^{\circledR}$, Nurofen Period Pain ${ }^{\circledR}$, Nurofen Tension Headaches ${ }^{\circledR}$, Nurofen Migraine Pain ${ }^{\circledR}$ and Nurofen Back Pain ${ }^{\circledR}$ ) was fined $\$ 6$ million by the Australian Consumer Law for misleading consumers with its specific pain relief range.

Names for products that contain the identical active ingredient(s) but have different indications of use should be avoided. For example, Prozac ${ }^{\circledR}$, an antidepressant, and Sarafem ${ }^{\circledR}$, for premenstrual dysphoric disorder, contain the same active ingredient (fluoxetine), which may lead, when taken at the same time, to overdose.

Names that are identical or nearly identical to that of a marketed foreign product that contains an entirely different active ingredient should also be avoided. For example, Trexan ${ }^{\circledR}$ treats addiction (naltrexone) in the United States and cancer (methotrexate) in Finland.

The sponsor's name should not be incorporated across multiple products, although as with Roche, it may not be obvious for every consumer: Rohypnol ${ }^{\circledR}$, Roaccutane ${ }^{\circledR}$, RoACTEMRA ${ }^{\circledR}$, Rocaltrol ${ }^{\circledR}$, Rocephin ${ }^{\circledR}$ and Roferon-A ${ }^{\circledR}$ are all marketed by Roche.

The FDA also advises that the brand name should be the same in all countries and be subjected to name simulation studies that should reflect the full range and variety of tasks involved in the prescribing, transcribing, dispensing, and administration of drugs.

While the guidance focuses primarily on safety-related aspects of proprietary names, the FDA also gives recommendations as to avoid misbranding the product by making "misrepresentations with respect to safety or efficacy" (e.g. prefixes like best- or superthat would imply superiority). For instance, the name of the antidepressant Rexulti ${ }^{\circledR}$ manufactured by Otsuka America Pharmaceutical plays on the two words "result" and "exult" making believe that the drug is efficacious ("result") in bringing joy ("exult").

Sponsors, or rather branding institutes, can resort to numerous linguistico-semantic strategies and lexicographic matrices to create memorable brand names. They can combine prefixes, infixes and suffixes $\left(\right.$ Oralair $\left.^{\circledR}\right)$, clip words and make up blends (Flucelvax ${ }^{\circledR}$ from $f l u$ "influenza", cel "cell" and vax "vaccine"), pick up ideophonic elements $\left(\right.$ Grastek $\left.^{\circledR}\right)$ and use sounds symbolism (Zeviate $\left.{ }^{\circledR}\right)$, borrow words from other languages - especially Romance languages such as Italian (Impavido ${ }^{\circledR}$ ), even create a matrix such as that made of "a letter+an existing (or non-existing) lexeme" (Qsymia ${ }^{\circledR}$ ), or simply assemble - often Greek and Latin - roots that give information for instance about the anatomic part (Spinraza ${ }^{\circledR}$ for the spine). 


\section{Letter symbolism}

Drug sponsors and branding institutes have a preference for certain letters whether it is because they look good in prints like $\mathrm{X}$, or because they have the right connotation like $\mathrm{Z}$ and its sound $[\mathrm{z}]$ associated with the idea of relaxation. In 20I I, Amit and Ankit Gangwal wrote:

The marketing industry has been infatuated to letter X e.g. Nexium, Clarinex, Celebrex, $[\ldots]$, Corex, Xanax, [...] and Zithromax. These letters are popular because they look better in print, make sounds people like saying and are associated with innovation. Moreover this flamboyant and swashbuckling letter $\mathrm{X}$ is associated with science fiction, high tech, computers, and automobiles. (3)

According to Adrian Room (I982), " $\mathrm{X}$ is a 'target' letter, drawing the eye to its central point at the cross of two diagonals" (I95). It has several very positive symbolic associations and is being used in many fields (e.g. genetics, algebra, sex, spirituality, science fiction, etc.).

Some brand names can even comprise two Xs in a row: Bevy $\mathbf{x X} \mathbf{x}^{\circledR}$ is an oral anticoagulant indicated for prophylaxis of venous thromboembolism and was named after its molecule betrixaban, the factor it inhibits (Factor $\mathrm{Xa}$ ) and its extended duration prophylactic form $(\mathrm{X})$.

Another popular letter is O. Mostly used as a suffix, it also looks good in print with its perfect rounded form that reminds of the human eye and mouth (Room I982).

Among the recently approved drugs, the name Xofigo ${ }^{\circledR}$ (a treatment of prostate cancer) is composed of X for X ray - the drug is radioactive -, and figo "fig" whose shape is that of the prostate gland, the suffix $\mathrm{O}$ forming a masculine proper name and giving the word an Italian sound.

For a long time, letter $\mathrm{Z}$ occupied a prominent position. At a time when drug names tended to start with a letter commonly used in everyday language, sponsors thought that using $\mathrm{Z}$ as an initial would make the drug more memorable. Between I986 and 2003 , drug names starting with $Z$ increased by $400 \%$ (Stepney 20I0). We all remember blockbusters such as Zyban ${ }^{\circledR}$ to stop smoking; Zoloft ${ }^{\circledR}$, an antidepressant; Zocor ${ }^{\circledR}$ to treat hyperlipidemia; Ziloric ${ }^{\circledR}$ for gout; and the three antibiotics Zinnat ${ }^{\circledR}$, Zeclar ${ }^{\circledR}$ and Zithromax ${ }^{\circledR}$.

We even talked about "Z-drugs", a class of non-benzodiazepine hypnotics used in the treatment of insomnia, and whose names started with Z: Zopiclone ${ }^{\circledR}$, Zaleplon ${ }^{\circledR}$ and Zolpidem ${ }^{\circledR}$.

Yet, from $20 \mathrm{I} 2$ to $20 \mathrm{I} 7$, only I4 $(4.3 \%)$ drug names started with $\mathrm{Z}$ among which we report two "Z-drugs" but with the letter $Z$ not as initial: Intermezzo ${ }^{\circledR}$, which still utilizes zolpidem as its active ingredient and whose name is borrowed from Italian and means “a composition which fits between two musical or dramatic entities"; and Hetlioz ${ }^{\circledR}$ to treat non-24-h sleep-wake disorder in totally blind individuals.

Another important criterion is pronunciation. Letters, when pronounced, convey sensations and emotions. We know, for example, that $\mathrm{X}$ when in initial is pronounced $[\mathrm{z}]$, and it should not come as a surprise that we found it in association with drugs that are supposed to relieve allergies $\left(\mathrm{Xyzal}^{\circledR}\right)$, pain $\left(\mathrm{Xermelo}^{\circledR}\right.$ from the Latin mel "honey" known to have soothing properties), and rheumatisms (Xeljanz ${ }^{\circledR}$ from Janus, 
itself derived from Janus Kinase, the name of the targeted protein, after Janus, the two-faced god, by analogy with the protein's two phosphorylation domains).

Overall, in our corpus, we noticed that there were fewer $Z$ and $X(4 \cdot 3 \%)$ as initials. Besides the fact that an excess of $\mathrm{Z}$ and $\mathrm{X}$ has ended drowning the drugs, USAN has placed a moratorium - at least for generic drug names - arguing that the two letters were too close phonetically and might lead to prescribing and dispensing errors. Likewise, USAN has banned letters $\mathrm{H}, \mathrm{J}, \mathrm{K}$ and $\mathrm{W}$, when placed as initials, on the grounds that they might not exist in all languages or have a different sound (Gangwal and Gangwal 20II). In our corpus, out of 320 drug names, we found none starting with W, only six starting with $\mathrm{H}$ ( $\mathrm{I} .8 \%$ ), five with $\mathrm{J}$ ( $\mathrm{I} .5 \%)$, but still I4 with $\mathrm{K}(4.3 \%)$ which has always been popular among trade name creators as it is eye-catching (Room 1982, I96). The two most prevalent initial letters were S $(9 \%)$ - it is also the case in the general language, according to the online Oxford Living Dictionary -, and A ( $7.5 \%)$, which has the known advantage of placing the name first in the alphabetical order.

We also noted a high prevalence of "vowel $+/ \mathrm{k} /$ " endings $(24$ names, i.e. $8 \%$ ) with a preference for the $-i q / k$ [Ik] ending (I6 names) such as Prepopik ${ }^{\circledR}$, a bowel cleansing product; Cometriq ${ }^{\circledR}$ and Tecentriq ${ }^{\circledR}$, two anti-cancer agents; Cotellic ${ }^{\circledR}$, a treatment of melanoma; Movantik ${ }^{\circledR}$, for constipation; Srensiq ${ }^{\circledR}$, for infantile hypophosphatasia; Zurempic ${ }^{\circledR}$, for an excess of uric acid; Siliq ${ }^{\circledR}$, for psoriasis; Belviq ${ }^{\circledR}$, to treat obesity; and Myrbetriq ${ }^{\circledR}$, to treat hyperactive bladder; -aq/k: Beleodak ${ }^{\circledR}$, for lymphoma; Fulyzaq ${ }^{\circledR}$, an antidiarrheal; and Farydaq ${ }^{\circledR}$, for multiple myeloma; and -eq: Triumeq ${ }^{\circledR}$, for HIV; Neuraceq ${ }^{\circledR}$, a contrast product. In phonosemantics, these "vowel $+/ \mathrm{k} /$ " endings have been shown to evoke rapidity, alertness and dynamism (Agrawal 20I6), all useful associations for a drug.

\section{The non-traditional letter string}

For a few years, we have observed a marked tendency to use a lexeme - either imaginary or not - preceded by a letter such as Kcentra ${ }^{\circledR}$ for the reversal of vitamin K antagonist therapy-induced coagulation factor deficiency, and Iclusig ${ }^{\circledR}$, a treatment of myeloid.

Among the consonants used in initial, we observed a preference for letter Q [kiv] probably to convey the idea of "quality" (Qsymia ${ }^{\circledR}$ whose name is formed of symia "a good-looking girl” in American slang is a treatment of obesity; Qnasl ${ }^{\circledR}$, from nasal, is a nebulizer for allergic rhinitis; Qtern ${ }^{\circledR}$ for the treatment of inadequately controlled type II diabetes; and Qudexy ${ }^{\circledR}$ for the treatment of partial onset and primary generalized tonic-clonic seizures); and letter X [e/rks] (Xtoro ${ }^{\circledR}$ formed of “ex" for "extern”, the drug treating acute otitis externa; Xtandi ${ }^{\circledR}$, a treatment of prostate cancer whose name sounds like "extant"; and Xgeva ${ }^{\circledR}$ for the treatment of osteoporosis).

We found five names made of "V [vi/var] + lexeme": Vimizim ${ }^{\circledR}$ for mucopolysaccharidosis; Viberzi ${ }^{\circledR}$ to treat irritable bowel syndrome; Vibativ ${ }^{\circledR}$ for infection, whose name sounds like "combative"; Vizamyl ${ }^{\circledR}$, a radioactive diagnostic drug for use with positron emission tomography imaging of the brain; and Vyzulta ${ }^{\circledR}$ to treat intraocular pressure in patients, whose name is made of $v y$ [vI] for "vision" and ult from "result". Apart from evoking "victory", "V" as initial has other useful associations such as "vital" (Room I982, I96). 
Others are less obvious as the consonant is phonetical such as [el] L (Elelyso ${ }^{\circledR}$ for long-term enzyme replacement therapy to treat a form of Gaucher disease (GD), whose name is made of lyso for "lysosome", GD being a lysosomal storage disease, and Eliquis ${ }^{\circledR}$ to reduce the risk of stroke and dangerous blood clots, whose name is formed of "liquefy", the drug's mode of action); [em] M (Emflaza ${ }^{\circledR}$ to treat patients with Duchenne muscular dystrophy and named after the molecule, deflazacort; and Empliciti ${ }^{\circledR}$ to treat people with multiple myeloma and whose name reminds us of "simplicity"); and [en] $\mathrm{N}$ (Entresto ${ }^{\circledR}$ to treat heart failure).

We found seven cases of "O+lexeme", which makes it the most popular "Vowel+lexeme" matrix: Ocaliva ${ }^{\circledR}$ to treat rare, chronic liver disease and in the name of which one can hear ['livə] "liver"; Ocrevus ${ }^{\circledR}$ to treat patients with relapsing and primary progressive forms of multiple sclerosis and named after the molecule it contains (ocrelizumab); Odomzo ${ }^{\circledR}$ to treat patients with locally advanced basal cell carcinoma; Ofev ${ }^{\circledR}$ for pulmonary fibrosis, whose name is composed of O for "orphan" (it was designated as an orphan medicinal product) and FEV for "Forced Expiratory Volume", which the drug is supposed to help; Olysio ${ }^{\circledR}$ to treat chronic hepatitis $\mathrm{C}$ virus infection, whose name is made of $\mathrm{O}$ for "oral"; Otezla ${ }^{\circledR}$ to treat adults with active psoriatic arthritis; and Omontys ${ }^{\circledR}$ to treat anemia, whose name contains Omon from "once-monthly" and $y s$ from "dialysis", as the drug, which was withdrawn in 20I4, was intended for patients on dialysis.

This matrix offers the huge advantage of allowing the creation of a two- or three-syllable sounding name while making it look short in writing and can be entered into more complex structures such as with HyQvia ${ }^{\circledR}$, an immune globulin infusion with recombinant human hyaluronidase (Hy-) for the treatment of primary immunodeficiency.

\section{Culture-related sound symbolism and Italian sounding}

"Foreign branding" is an advertising and marketing term describing the use of foreign or foreign-sounding brand names for companies, products, and services in order to increase desirability or perceived value. The studies led by Leclerc et al. (I994) have demonstrated that foreign branding can have a significant effect on brand associations and attitudes.

Shrum and his colleagues (Lowrey and Shrum 2007; Shrum et al. 20I2) who investigated the effects of phonetic symbolism on brand name preference have indicated that phonetic symbolism effects for brand name perceptions can generalize across languages, and they have thus suggested that, although the brand naming process is made much more difficult by the globalization of markets, marketers might be able to embed universal meaning in their brand names.

Italian is usually associated with food, coffee, man's clothing, and expensive cars, all of high quality, and is often used in automotive (e.g. Kia Niro ${ }^{\circledR}$, Nissan Navara ${ }^{\circledR}$, Opel Insignia ${ }^{\circledR}$, etc.) and food (e.g. chocolate powder Milo ${ }^{\circledR}$, Molico $^{\circledR}$ and Benco ${ }^{\circledR}$, milk Nido $^{\circledR}$, etc.).

In our corpus, we found some drug names that we claim were clearly created so as to be associated with famous coffee brands such as Natesto ${ }^{\circledR}$, a nasal gel for the treatment of deficiency or absence of endogenous testosterone and whose name is made of the prefix nas-for nasal and testo for "testosterone" but which is very cleverly built so as to resemble the coffee brand Nespresso by Nestlé's. Another example is Tagrisso ${ }^{\circledR}$ (osimertinib) 
to treat a certain type of non-small cell lung cancer and whose name (composed of $\mathrm{T}$ for $\mathrm{T}_{790} \mathrm{M}$, the targeted mutation, agriss for "aggression" - this form of cancer being particularly resistant) resembles Tassimo ${ }^{\circledR}$. Afrezza ${ }^{\circledR}$, human insulin inhalation powder for the treatment of diabetes mellitus, Ingrezza ${ }^{\circledR}$ to treat adults with tardive dyskinesia, and Portrazza ${ }^{\circledR}$, an anticancer drug, all echo Lavazza ${ }^{\circledR}$, an eponymic Italian coffee brand.

As generally acknowledged, we noticed that the feminine sounding A ending was indeed used in names of drugs that treated diseases commonly associated with women some of which contained a woman's name such as Natazia ${ }^{\circledR}$ for the treatment of heavy menstrual bleeding; Intrarosa ${ }^{\circledR}$ for the treatment of dyspareunia, made of the woman's name Rosa and the prefix intra, the route of administration being vaginal insertion; Lynparza ${ }^{\circledR}$ to treat advanced ovarian cancer, a name composed of "Lyn", which we also found in Linzess ${ }^{\circledR}$ to help relieve symptoms associated with irritable bowel syndrome; Zejula ${ }^{\circledR}$ for the maintenance treatment for recurrent epithelial ovarian and fallopian tube cancer and whose name reminds us of "Julia"; and Kevzara ${ }^{\circledR}$ to treat adult rheumatoid arthritis, made of the woman's name "Zara”. Others sounded like a woman's name such as Rubraca ${ }^{\circledR}$, to treat women with a certain type of ovarian cancer, and which sounds like "Rebecca".

Among the names that sounded feminine and were associated with female conditions, we noted Osphena ${ }^{\circledR}$ for dyspareunia; Belsomra ${ }^{\circledR}$ (bel "beautiful"+som- "sleep") for insomnia; Lenvima ${ }^{\circledR}$ to treat patients with progressive, differentiated thyroid cancer; and Perjeta ${ }^{\circledR}$ to treat patients with metastatic breast cancer. We also found the A ending in names of drugs for lung cancer, which confirms that the condition is on the increase among women: Alecensa ${ }^{\circledR}$ to treat ALK-positive lung cancer; Portrazza ${ }^{\circledR}$ and Zykadia ${ }^{\circledR}$ to treat patients with metastatic squamous non-small cell lung cancer.

But we also found the A ending in the name of drugs for male cancers such as Zytiga ${ }^{\circledR}$ and Jevtana ${ }^{\circledR}$ to treat metastatic prostate cancer.

Conversely, we found the masculine $\mathrm{O}$ ending in names of drugs that were treatments of cancers deemed to be more common in women: Verzenio ${ }^{\circledR}$ to treat certain advanced or metastatic breast cancers, and Marqibo ${ }^{\circledR}$, indicated for the treatment of adult patients with Philadelphia chromosome-negative acute lymphoblastic leukemia, whose name evokes a marquis. We claim that the masculine-connoted $\mathrm{O}$ ending has two functions: turning the drug into a companion by lending to it a man's attributes and thereby giving the impression of power.

Out of the 320 drugs of our corpus, I26 ended with either A or O (almost $40 \%$ ). Out of these I26 names, I7 had an "alveolar fricative+A" [zæ/sæ $]$ ending among which Io had been FDA approved after 20I5. In the Chambers Dictionary, which comprises about 45,000 headwords, there are about 200 words with such ending, which makes the $\mathrm{I} 3.5 \%$ figure found in our corpus unusually high.

Aside of playing on the high quality and refinement associated with Italian sounding brands, we suspect sponsors to also resort to A and O endings to reach Spanish and Portuguese speaking clients on the American continent as well as Romance languages speaking ones on the European continent. 


\section{Word-conveyed connotation}

Contrary to the FDA's recommending that the name should not be overly promising, our corpus elicited many examples that conveyed ideas such as innovation or reliability. Indeed, like with any other marketing, the drug-brand consulting industry tries to transmit messages via the name. For example, Viagra ${ }^{\circledR}$ is made of $v i$ - for "vigor" or "vitality", and Niagara "suggesting a mighty flow". But the reasons that lead the sponsor to choose a given name can be so clever that they might be beyond most people's understanding. According to the information supplied by Vertex Pharmaceuticals Incorporated that made the drug, the name Orkambi ${ }^{\circledR}$, a treatment for cystic fibrosis, made of the prefix or-, which designates the route of administration (oral) and the suffix-ambi owing to the presence of two molecules working together, aims at evoking the Japanese "origami", which underlines the drug's protein folding function.

Wishing to highlight the progress that underlies their novel drug, sponsors like to convey the idea of innovation by resorting to affixes like [nu:] the phonetical version of - new such as in $\mathbf{N u c a l a}{ }^{\circledR}$, an antiasthmatic, Nuwiq ${ }^{\circledR}$ for the prophylaxis and treatment of hemophilia A, Nuplazid ${ }^{\circledR}$, an antipsychotic, and Kanuma ${ }^{\circledR}$, to treat patients with a rare disease known as lysosomal acid lipase deficiency; and its Latin translation novasuch as in Epanova ${ }^{\circledR}$ for the treatment of severe hypertriglyceridemia.

The idea of innovation is also conveyed in Dalvance ${ }^{\circledR}$ for the treatment of acute bacterial skin infections, and Bavencio ${ }^{\circledR}$, to treat metastatic Merkel cell carcinoma, whose names remind us of "advance"; and Descovy ${ }^{\circledR}$, for the treatment of HIV-I infection, whose name sounds like "discovery". Tecfidera ${ }^{\circledR}$ to treat adults with relapsing forms of multiple sclerosis, Tecentriq ${ }^{\circledR}$ to treat urothelial carcinoma, and Grastek ${ }^{\circledR}$ and Ragwitek ${ }^{\circledR}$ for ragweed pollen-induced allergic rhinitis, all include the affix -tec/k-for "technology".

The affix -gen- evokes the progress made in pharmacogenomics. It can be used as prefix as in Genvoya ${ }^{\circledR}$, indicated as a complete regimen for the treatment of HIV-I infection, or as suffix as in Ziagen ${ }^{\circledR}$, another anti-retroviral, and Epogen ${ }^{\circledR}$, a treatment of anemia.

Another desirable idea is that of "truth", which we found in Trulicity ${ }^{\circledR}$, destined to improve glycemic control in type II diabetics; Trulance ${ }^{\circledR}$ to treat chronic idiopathic constipation in adult patients; Keytruda ${ }^{\circledR}$ made of "key" and truda, which reminds us of "intruder", for the treatment of unresectable or metastatic melanoma; Liptruzet ${ }^{\circledR}$ for the treatment of hyperlipidemia; Lartruvo ${ }^{\circledR}$, to treat adults with certain types of soft tissue sarcoma; and Vraylar ${ }^{\circledR}$ for acute manic episodes of bipolar disorder and schizophrenia in adults (made of the French vrai "true").

Other names convey ideas of "power" and "efficacy" such as Onzetra Xsail ${ }^{\circledR}$ (Xsail "XL" and "exhale" as the delivery system sends the drug directly to the back of the nose) for the treatment of migraine; Farxiga ${ }^{\mathbb{B}}($ far $+\mathrm{X})$ for the treatment of type II diabetes; Signifor ${ }^{\circledR}$ ("signify/significant") for the treatment of acromegaly; and Afinitor ${ }^{\circledR}$ ("affinity"), for breast cancer, both ending with the powerful suffix -or, which is found at the end of heroes' names (Thor and Terminator); Ultresa ${ }^{\circledR}$ to treat exocrine pancreatic insufficiency and whose name starts with $u l t r$ - for "ultra"; Orbactiv ${ }^{\circledR}$, for the treatment of acute bacterial skin infections and Briviact ${ }^{\circledR}$, an antiepileptic (both contain the word active); Rapivab ${ }^{\circledR}$ (rapid) for the treatment of acute uncomplicated influenza in adults; Bespons $a^{\circledR}$ to treat adults with relapsed or refractory acute lymphoblastic leukemia, a portmanteau word made of best and response; and Nerlynx ${ }^{\circledR}$ aimed at reducing the risk 
of breast cancer returning, whose name is made of Ner-after the molecule neratinib and contains the word "lynx", an animal supposed to be keen on vision (e.g. lynx-eyed) - but also "links" phonetically - thereby giving the impression that signs of relapse will be monitored efficiently.

Musical connotations are quite popular in our corpus: Lyrica ${ }^{\circledR}$ (antiepileptic); Intermezzo ${ }^{\circledR}$ (sleeping aid); Aubagio ${ }^{\circledR}$ (to treat relapsing forms of multiple sclerosis), which is a portmanteau word made of "aubade" and "adagio"; Quartette ${ }^{\circledR}$ (contraceptive), whose French suffix - ette has a feminine association (e.g. suffragette, bachelorette, etc.); Anthim ${ }^{\circledR}$ (for treatment and prevention of inhalational anthrax) "anthem"; and Harvoni ${ }^{\circledR}$ (for the treatment of hepatitis C), which sounds like "harmony".

We suspect the sponsors and branding institutes of borrowing from Western culture and more precisely from television series (Faure 20I4) with Tudorza ${ }^{\circledR}$, a drug for Chronic Obstructive Pulmonary Disease (COPD) (from The Tudors), and Alecensa ${ }^{\circledR}$ (from Sansa in Game of Thrones); from literature with Oxtellar ${ }^{\circledR}$ (an antiepileptic), which reminds us of Othello, and Odefsey ${ }^{\circledR}$, a treatment of HIV-I, which sounds like "odyssey"; from mythology with Xartemis ${ }^{\circledR}$ (a painkiller), Varithena ${ }^{\circledR}$, which sounds like Athena, a treatment of varicose veins, and Elelyso ${ }^{\circledR}$ whose name sounds like "Elysium".

\section{Conclusion}

Considering the huge amount of money devoted to the marketing of new drugs, drug sponsors cannot take the risk of releasing a drug that will not sell. As seen with the contrasting stories of the two brands of lisinopril, both launched in the late I980s: "ICI Pharmaceuticals called its lisinopril Zestril. Its competitors marketed the same molecule as Carace. Whereas Zestril became one of the medical world's most successful brands, Carace sank pretty much without trace" (Stepney 20IO, I3I7), the choice of a name is crucial. Even more so as over 30,000 prescription drugs are trademarked in the United States - nearly I 50,000 in Europe -, and as the FDA approves dozens of new drugs every year after rejecting about a third of all applications. Not to mention the fact that $70 \%$ of the newly approved drugs are "me-too" drugs that contain the same molecule(s) as their previously approved originals. Yet, because medication errors account for an estimated 7000 deaths annually in the United States, the FDA has issued a guidance to help sponsors of human drugs develop proprietary names, and henceforth screening of brand names today has been under more scrutiny. In addition, as the world pharmaceutical industry is becoming increasingly globalized, ideally a name has to work in other languages and other cultures. Therefore, creating a unique name has become more of a challenge.

In our study, we have shown that the commonly used letters $\mathrm{X}$ and $\mathrm{Z}$ are giving way to $\mathrm{A}$ and $\mathrm{O}$ endings so as to attract Romance languages speaking clients and conquer other markets such as the Latin American and the European markets. We have demonstrated that this trend matches a less recent ploy in food and automotive marketing. We focused on the "Vowel/Consonant+lexeme" matrix that is found almost exclusively in the drug industry because it permits to create a name shorter in writing - an advantage for prescribers. Although the FDA recommended that "unsubstantial beneficial" connotations be banned, we have uncovered the presence of promotional affixes as well as hidden emotional contents that are meant to be persuasive. 
From the first local apothecaries that distributed their botanical drugs that bore the names of the plants they contained to multinational corporations that register names before they even have a drug to fit them, the pharmaceutical industry has evolved and so has the status of the drugs they sell: they have become like any other ordinary consumer goods thereby turning patients into ordinary consumers.

\section{Notes}

r. For more information on patents and exclusivity, see: < http://www.fda.gov/Drugs/Development ApprovalProcess/ucmo7903r.htm>.

2. For more information on the reviewing process, see: $<$ https://www.fda.gov/downloads/drugs/drugsafety/ medicationerrors/ucmo80867.pdf $>$.
3. For information on FDA's recommendations on drug names, see: <http://www.fda.gov/downloads/ drugs/guidancecomplianceregulatoryinformation/ guidances/ucm 398997.pdf>.

4. For the list of stems used by the World Health Organization (WHO), see: <http://www.who.int/ medicines/services/inn/StemBook_2OII_Final.pdf>.

\section{Bibliography}

Agrawal, Pramod Kumar. 20I6. Meaningfulness of Sounds. Jaipur: Universal Theory Research Centre.

Faure, Pascaline. 20I4. “Du sildénafil citrate au Viagra ${ }^{\circledR}$ ou l'art délicat de nommer les médicaments.” [From Sildenafil Citrate to Viagra ${ }^{\circledR}$ or the Delicate Art of Naming Drugs] Terminology 20 (I): 74-9I.

Gangwal, Amit, and Ankit Gangwal. 20Iг. "Naming of Drug Molecules and Pharmaceutical Brands." Journal of Current Pharmaceutical Research 7 (I): OI-O5.

Leclerc, France, Bernd Schmitt, and Laurette Dubé. I994. "Foreign Branding and Its Effects on Product Perceptions and Evaluations." Journal of Marketing Research 31: 263-270.

Lowrey, Tina, and L. J. Shrum. 2007. "Phonetic Symbolism and Brand Name Preference." Journal of Consumer Research 34: 406-4I4.

Room, Adrian. I982. Dictionary of Trade Name Origins. London: Routledge and Kegan Paul Ltd.

Shrum, L. J., Tina Lowrey, David Luna, Dawn Lerman, and Min Liu. 20I2. "Sound Symbolism Effects across Languages: Implications for Global Brand Names.” International Journal of Research in Marketing 29 (3): $275-279$.

Stepney, Rob. 20I0. "A Dose by Any Other Name Would Not Sell as Sweet.” BMJ: British Medical Journal 34I, no. 7786: I3I6-3I7. http://www.jstor.org/stable/25766562 (accessed December 27, 20I7).

\section{Notes on contributor}

Pascaline Faure is a Professor in medical English. She is the head of Pierre and Marie Curie University's medical English department. She takes a special interest in the lexicological and the cultural aspects of English and French for medical purposes. She holds a $\mathrm{PhD}$ in linguistics but she also studied medicine.

Correspondence to: Professor Pascaline Faure, Faculté de médecine Pierre et Marie Curie, Département d'anglais médical, 9I bd de l'Hôpital, 750I 3 Paris, France. Tel: oo 336743570 34; Email: pascalinefaure@orange.fr 